\title{
Editorial
}

\section{Tooth bug catcher - A new euphemism for endodontic files in children}

\author{
Vipin Ahuja ${ }^{1, *}$ \\ ${ }^{1}$ Dept. of Pediatric and Preventive Dentistry, Hazaribag College of Dental Sciences and Hospital, Hazaribagh, Jharkhand, India
}

\section{A R T I C L E I N F O}

Article history:

Received 05-08-2021

Accepted 12-08-2021

Available online 20-08-2021
This is an Open Access (OA) journal, and articles are distributed under the terms of the Creative Commons Attribution-NonCommercial-ShareAlike 4.0 License, which allows others to remix, tweak, and build upon the work non-commercially, as long as appropriate credit is given and the new creations are licensed under the identical terms.

For reprints contact: reprint@ipinnovative.com
Behavior management in pediatric dentistry is sketchily done by two means, non-pharmacological and pharmacological. The 'pharmacological' refers to drug, pharmacy etc. and when these drugs or pharmacy is involved in controlling behavior of the child, it is known as pharmacological means of behavior management. It is usually done by nitrous oxide conscious sedation or general anaesthesia. And, when no drug or pharmacological means are involved, it is known as non-pharmacological method. This involves lot of techniques and methods and is always the first step of managing behavior of children in Pediatric Dentistry. The fundamental and universal technique in this category is communication, both verbal and non-verbal. Communication is simply defined as the way of exchanging ideas with each other. ${ }^{1}$ The way in which a pediatric dentist communicates with the child patient, lays the cornerstone of child behavior management in pediatric dental practice. Fear and anxiety are two emotions that can be ebbed by proper communication. The message from the operator to the child should be clear, precise and in simple words. And, there comes the use of 'Euphemisms' in picture.

Euphemisms are substitute words used in place of scientific words, which are difficult to comprehend by the child to make him understand the procedure in a simple way. It is also known as a second language. It is an imperative fragment of non-pharmacological means of behavior management in pediatric dentistry. There are a lot

\footnotetext{
* Corresponding author.

E-mail address: drvipinahuja@gmail.com (V. Ahuja).
}

of euphemisms used in dentistry for children as follows: ${ }^{2,3}$

\begin{tabular}{ll}
\hline Scientific word & Euphemism \\
Caries & Sugar bugs \\
Local Anaesthesia & Sleepy water/ medicine \\
Impression material & Pudding \\
Rubber dam & Rain coat \\
Rubber dam clamp & Tooth button \\
Rubber dam frame & Coat rack \\
Sealant & Tooth paint \\
Study models & Statues \\
X-ray machine & Camera \\
Radiograph & Picture \\
Handpiece & Whistling train \\
Stainless steel crown & Hat for the tooth \\
Bur & Brush/ Pencil \\
Suction/ Evacuator & Vacuum cleaner \\
Fluoride varnish & Tooth vitamins \\
Air syringe & Wind gun \\
Water syringe & Water gun \\
Endodontic files in children & Tooth Bug Catcher ${ }^{4}$ \\
\hline
\end{tabular}

A new euphemism, 'Tooth Bug Catcher' for 'Endodontic files used for root canal treatment in young children' is now added to the literature of pediatric dentistry by Vipin Ahuja and Annapurna Ahuja (Registered in the Copyright Office, Government of India with registration no. L104586/2021). ${ }^{4}$ At the outset, Euphemisms are a collection of simple words which are also known as substitute words used frequently in dentistry for children. 


\section{Conflict of Interest}

None.

\section{References}

1. Wright GZ. Behavior management in dentistry for children. In: 1st Edn. W.B. Saunders Co; 1975

2. Tandon S. Textbook of Pedodontics. In: 2nd Edn. Hyderabad, New Delhi, India: Paras Medical Publisher; 2009.

3. Marwah N. Textbook of Pediatric Dentistry. In: 4th Edn. New Delhi, India: Jaypee Brothers Medical Publishers (P) Ltd; 2018.

4. Copyright office, Government of India [Internet]; [updated 2019; cited 2021 June 25]; 2019. Available from: https://copyright.gov.in/ frmStatusGenUser.aspx.

\section{Author biography}

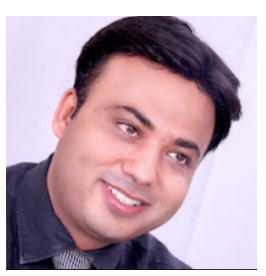

Vipin Ahuja, Professor \& Head,

Hazaribag College of Dental Sciences and Hospital, Hazaribagh, Jharkhand, India

Cite this article: Ahuja V. Tooth bug catcher - A new euphemism for endodontic files in children. J Dent Panacea 2021;3(2):46-47. 